\title{
Mutasi Gen CYP21 dan Manifestasi Klinis pada Hiperplasia Adrenal Kongenital
}

Ludi Dhyani Rahmartan, Jose RL Batubara, Setyo Handryastuti, Lamtorogung Prayitno

Departemen Ilmu Kesehatan Anak Fakultas Kedokteran Universitas Indonesia/Rumah Sakit Cipto Mangunkusumo, Jakarta

Latar belakang. Hiperplasia adrenal kongenital (HAK) adalah suatu kelainan genetik yang disebabkan oleh mutasi gen CYP21 yang bersifat autosomal resesif. Lebih dari 90\% kasus terjadi akibat defisiensi enzim 21-hidroksilase (21-OHD).

Tujuan. Mengetahui manifestasi klinis mutasi CYP21 pada anak dengan HAK.

Metode. Studi deskriptif retrospektif dilakukan selama Oktober-Desember 2014. Subjek adalah anak HAK yang terdaftar di Divisi Endokrinologi Anak RSCM dan pernah dilakukan pemeriksaan mutasi gen CYP21. Data diambil dari rekam medis, dan register HAK tahun 2009-2014.

Hasil. Didapatkan 45 subjek HAK (37 perempuan, 8 laki-laki) yang yang telah diketahui jenis mutasinya. Manifestasi klinis yang dijumpai adalah tipe salt wasting (SW) 33 subjek, simple virilizing (SV) 10 subjek, dan non-classic (NC) 2 subjek. Median usia saat terdiagnosis HAK pada tipe SW usia 1 bulan (0-3 bulan), tipe SV usia 3 tahun (2-6 tahun), dan tipe NC usia 5 tahun. Keluhan utama terbanyak adalah genitalia ambigus (60\%). Dua jenis mutasi (R356W dan I172N) ditemukan pada 21 subjek, mutasi R356W tunggal ditemukan pada 9 subjek, dan mutasi I172N tunggal ditemukan pada 15 subjek. Mutasi I172N ditemukan pada $80 \%$ alel, dan mutasi R356W pada 66,7\% alel.

Kesimpulan.Manifestasi klinis terbanyak pada penelitian ini adalah tipe SW yang memiliki dua jenis mutasi. Pemeriksaan mutasi gen CYP21 bermanfaat untuk konseling genetik, diagnosis prenatal dan tata laksana pada keluarga yang memiliki risiko HAK.

Sari Pediatri 2016;18(1):27-33

Kata kunci: hiperplasia adrenal kongenital, defisiensi 21-hidroksilase, mutasi CYP21

\section{CYP21 Gene Mutations and Clinical Manifestations of Children with Congenital Adrenal Hyperplasia}

Ludi Dhyani Rahmartan, Jose RL Batubara, Setyo Handryastuti, Lamtorogung Prayitno

Background. Congenital adrenal hyperplasia (CAH) is an autosomal recessive genetic disorder. More than $90 \%$ of cases are due to 21-hydroxylase deficiency which caused by CYP21 mutation.

Objective. Study the characteristic of CYP21 mutation and clinical manifestation in children with CAH.

Methods. A descriptive retrospective study was performed during October-December 2014. Subjects were CAH children who were admitted to Pediatric Endocrinology Cipto Mangunkusumo hospital and tested for CYP21 gene mutation. Data were taken based on parents' interview, medical records and CAH registry during 2009-2014.

Results. A total of 45 subjects (37 girls, 8 boys) participated, with clinical profile of salt wasting (SW) type found in 33 subjects, simple virilizing (SV) in 10 subjects, and non-classical (NC) type in two subjects. Median age of diagnosis in SW type is 1 month old (0-3 month), SV type is 3 years old (2-6 years), NC type is 5 years old. Ambigous genitalia was the major chief complaint (60\%). Two types of mutations (R356W and I172N) in 21 patients. Single mutation found in 9 patients (R356W), and 15 patients (I172N). I172N mutation was found in $80 \%$ alleles, followed by R356W in 66,7\% alleles.

Conclusion. The most common clinical manifestation in this study is SW type with two mutations. CYP21 mutation analysis may provide important information for genetic counseling, prenatal diagnosis and management of families at risk for CAH.

Sari Pediatri 2016;18(1):27-33

Keywords: congenital adrenal hyperplasia, 21-hidroxylase deficiency, CYP21 mutation

Alamat korespondensi: Dr. Ludi Dhyani Rahmartan. Departemen Ilmu Kesehatan Anak, Fakultas Kedokteran Universitas Indonesia/Rumah Sakit Cipto Mangunkusumo, Jakarta, E-mail: ludi_dhyani@hotmail.com 
$\mathrm{H}$ iperplasia adrenal kongenital (HAK) atau congenital adrenal hyperplasia $(\mathrm{CAH})$ adalah suatu kelainan genetik akibat adanya mutasi pada gen CYP21. Kelainan ini bersifat autosomal resesif, dengan insiden kasus HAK di dunia 1:10.000-20.000. Mutasi ini menyebabkan defisiensi enzim dalam jalur biosintesis steroid pada korteks adrenal. Lebih dari $90 \%$ kasus HAK disebabkan oleh defisiensi enzim 21-hidroksilase (21-OHD). ${ }^{1-6}$ Berdasarkan manifestasi klinis, kelainan ini dapat diklasifikasikan menjadi tipe klasik (salt wasting dan simple virilizing) dan non-classic (NC) ${ }^{1-}$ ${ }^{3}$ Defek pada enzim ini menyebabkan kemampuan sintesis hormon kortisol dan aldosteron berkurang, serta peningkatan produksi androgen secara berlebihan. Kadar kortisol yang rendah dapat menyebabkan anak dengan HAK meninggal setelah lahir akibat krisis adrenal. Produksi androgen yang berlebihan dapat menyebabkan virilisasi pada janin perempuan sehingga lahir dengan genitalia ambigus dan maskulinisasi. ${ }^{5-7}$

Seiring dengan perkembangan zaman, deteksi dini kasus HAK telah banyak dilakukan di berbagai negara di dunia. Deteksi ini meliputi uji saring neonatus dan pemeriksaan mutasi genetik. Mutasi gen CYP21 akan memengaruhi derajat defek enzimatik yang terjadi, dan akan memengaruhi manifestasi klinis. Sejumlah penelitian dari berbagai negara telah memperlihatkan hubungan genotip dan fenotip. Mutasi yang terjadi akan menentukan persentase aktifitas enzim 21-OH dan memengaruhi manifestasi klinis HAK. ${ }^{8-10}$ Hingga saat ini terdapat sekitar 100 mutasi CYP21 yang dilaporkan. dan diantaranya berkaitan dengan fenotip HAK. ${ }^{1,9-16}$

Pada studi beberapa negara di Asia ditemukan beberapa mutasi yang paling sering terjadi, serta korelasi antara genotip dan fenotip HAK dilaporkan mencapai 80\%-90\%. Mutasi $1001 \mathrm{~T}>\mathrm{A}$ pada ekson 4 yang mengakibatkan perubahan asam amino isoleusine menjadi asparagine (I172N) berhubungan dengan HAK 21-OHD tipe klasik simple virilizing. Mutasi $2110 \mathrm{C}>\mathrm{T}$ pada ekson 8 yang mengakibatkan perubahan asam amino arginine menjadi tryptophan (R356W) berhubungan dengan HAK 21-OHD tipe klasik salt wasting. Mutasi 1685 G>T pada ekson 7 yang mengakibatkan perubahan asam amino valine menjadi leucine (V281L) berhubungan dengan HAK 21-OHD tipe non-klasik. ${ }^{1,2,9,11}$ Di RSCM, telah dilakukan pemeriksaan mutasi CYP21 oleh Oswari $\mathrm{dkk},{ }^{17}$ tetapi hasilnya belum memuaskan.
Deteksi mutasi sangat penting untuk dilakukan terutama untuk konseling genetik pra-nikah, diagnosis pra-natal, skrining neonatal, dan diagnosis pasca-natal sehingga dapat dideteksi sebelum manifestasi klinis muncul yang menyebabkan morbiditas dan mortalitas. Penegakan diagnosis dini pada pasien HAK sangat diperlukan untuk mencegah kematian akibat krisis adrenal, mendapatkan tata laksana jangka panjang yang adekuat, memiliki tumbuh kembang yang normal, dan mengurangi beban psikologis akibat kebingungan gender. ${ }^{4,7}$

\section{Metode}

Penelitian deskriptif dengan menggunakan desain studi retrospektif untuk mengetahui manifestasi klinis anak dengan HAK yang mengalami mutasi CYP21. Penelitian dilakukan di Divisi Endokrinologi Departemen IKA RSCM pada bulan Oktober hingga Desember 2014. Data mutasi gen CYP21 merupakan data sekunder dari penelitian Batubara, ${ }^{18}$ kemudian dilakukan pendataan ulang berdasarkan rekam medis di RSCM dan register HAK tahun 2009-2014.

\section{Hasil}

Didapatkan 45 orang subjek yang telah dilakukan pemeriksaan mutasi CYP21, dengan rasio laki-laki dibanding perempuan $(1: 4,6)$. Penentuan jenis kelamin berdasarkan pemeriksaan klinis dan hasil pemeriksaan kromosom. Karakteristik klinis dan demografi subjek tertera pada Tabel 1 .

Hampir seluruh subjek yang terdiagnosis sebelum usia 1 tahun adalah tipe SW (96,9\%). Subjek HAK tipe SW terdiagnosis dan mulai terapi lebih dini yaitu pada median 1 bulan (rentang 0-3 bulan), tipe SV pada median 3 tahun (rentang 2-6 tahun), dan tipe NC pada usia 5 tahun. Manifestasi klinis subjek diperinci berdasarkan tipe HAK dan tertera pada Tabel 2.

\section{Mutasi Gen CYP21}

Penelitian kami menggunakan data sekunder dari penelitian Batubara dengan metode Real-Time PCR SNPS Genotyping Assays menggunakan 7500 Fast Real-Time PCR Systems [Applied Biosystems]. ${ }^{18}$ Mutasi R356W 
Tabel 1. Karakteristik klinis dan demografi subjek penelitian

\begin{tabular}{|c|c|c|}
\hline \multirow{2}{*}{ Karakteristik subjek } & \multicolumn{2}{|c|}{ Jumlah } \\
\hline & $\mathrm{n}$ & $\%$ \\
\hline \multicolumn{3}{|c|}{ Jenis kelamin berdasarkan analisis kromosom $(\mathrm{n}=45)$} \\
\hline Laki-laki (46XY) & 8 & 17,8 \\
\hline Perempuan (46XX) & 37 & 82,2 \\
\hline \multicolumn{3}{|c|}{ Usia saat terdiagnosis HAK (tahun, $\mathrm{n}=45$ ) } \\
\hline$<1$ & 37 & 82,2 \\
\hline$\geq 1$ & 8 & 17,8 \\
\hline \multicolumn{3}{|c|}{ Riwayat keluarga HAK ( $\mathrm{n}=45)$} \\
\hline Ada & 7 & 15,6 \\
\hline Tidak & 38 & 84,4 \\
\hline \multicolumn{3}{|l|}{ Konsanguitas ( $\mathrm{n}=45)$} \\
\hline Ada & 0 & 0 \\
\hline Tidak & 45 & 100 \\
\hline \multicolumn{3}{|c|}{ Keluhan utama pertama kali $(\mathrm{n}=45)$} \\
\hline Genitalia ambigus & 27 & 60 \\
\hline Krisis adrenal & 16 & 35,6 \\
\hline Riwayat keluarga HAK & 2 & 4,4 \\
\hline \multicolumn{3}{|l|}{ Tipe HAK $(n=45)$} \\
\hline Salt wasting (SW) & 33 & 73,3 \\
\hline Simple virilizing (SV) & 10 & 22,2 \\
\hline Non-classic (NC) & 2 & 4,5 \\
\hline
\end{tabular}

Keterangan: HAK (hiperplasia adrenal kongenital), 17-OHP (17-hidroksiprogesteron)

Tabel 2. Karakteristik subjek penelitian berdasarkan tipe HAK

\begin{tabular}{|c|c|c|c|}
\hline \multirow{2}{*}{ Karakteristik subjek } & \multicolumn{3}{|c|}{ Tipe HAK } \\
\hline & salt wasting $(\mathrm{n})$ & simple virilizing $(\mathrm{n})$ & non-classic (n) \\
\hline \multicolumn{4}{|l|}{ Jenis kelamin } \\
\hline Perempuan $(\mathrm{n}=37)$ & 26 & 9 & 2 \\
\hline Laki-laki $(\mathrm{n}=8)$ & 7 & 1 & 0 \\
\hline \multicolumn{4}{|l|}{ Usia saat terdiagnosis (tahun) } \\
\hline$<1(\mathrm{n}=37)$ & 32 & 5 & 0 \\
\hline$\geq 1(\mathrm{n}=8)$ & 1 & 5 & 2 \\
\hline \multicolumn{4}{|l|}{ Riwayat keluarga HAK } \\
\hline Ada $(\mathrm{n}=7)$ & 6 & 1 & 0 \\
\hline Tidak ada $(\mathrm{n}=38)$ & 27 & 9 & 2 \\
\hline \multicolumn{4}{|l|}{ Keluhan pertama kali } \\
\hline Genitalia ambigus $(\mathrm{n}=27)$ & 16 & 9 & 2 \\
\hline Krisis adrenal $(\mathrm{n}=16)$ & 15 & 1 & 0 \\
\hline Riwayat HAK $(\mathrm{n}=2)$ & 2 & 0 & 0 \\
\hline
\end{tabular}

ditemukan pada 30 subjek (66,7\%), terdiri atas 24 mutasi homozigot dan enam mutasi heterozigot. $\mathrm{Mu}-$ tasi $1172 \mathrm{~N}$ ditemukan pada 36 subjek (80\%) terdiri atas 18 mutasi homozigot dan 18 mutasi heterozigot.

Terdapat 21/45 (46,7\%) subjek mengalami dua jenis mutasi (R356W dan I172N) yang terdiri atas 15 subjek tipe SW, 5 tipe SV, dan 1 tipe NC. Subjek yang mengalami satu jenis mutasi, terdiri atas mutasi R356W 9 subjek, dan mutasi I172N 15 subjek (Tabel 3). 
Tabel 3. Jenis mutasi CYP21 dan subjek berdasarkan tipe HAK

\begin{tabular}{|c|c|c|c|c|}
\hline \multirow{2}{*}{ Mutasi yang terjadi } & & \multicolumn{3}{|c|}{ Jumlah subjek berdasarkan tipe HAK } \\
\hline & & salt-wasting & simple virilizing & non-classic \\
\hline R356W homozigot & / I172N homozigot & 9 & 0 & 0 \\
\hline R356W homozigot & / I172N heterozigot & 4 & 2 & 0 \\
\hline R356W heterozigot & / I172N homozigot & 2 & 1 & 0 \\
\hline R356W heterozigot & / I172N heterozigot & 0 & 2 & 1 \\
\hline R356W homozigot & & 6 & 3 & 0 \\
\hline I172N homozigot & & 5 & 0 & 1 \\
\hline I172N heterozigot & & 7 & 2 & 0 \\
\hline
\end{tabular}

\section{Pembahasan}

Tujuan penelitian kami adalah untuk mengetahui pola distribusi mutasi CYP21 (genotip) pada anak dengan HAK di Indonesia terkait dengan manifestasi klinis yang terjadi (fenotip). Telaah literatur yang telah dilakukan di seluruh dunia mengenai mutasi gen CYP21 menunjukkan hasil yang bervariasi. Sebagian besar laporan penelitian menunjukkan bahwa mutasi mutasi R356W berhubungan dengan HAK tipe klasik salt wasting dan I172N berhubungan dengan HAK tipe klasik simple virilizing. ${ }^{1,2,8}$ Penelitian mengenai hal ini di Indonesia sudah pernah dilakukan sebelumnya, tetapi belum dapat memberikan hasil yang memuaskan.

Subjek penelitian adalah 45 anak dengan HAK dengan rasio subjek perempuan dibandingkan laki-laki 4,6:1. Sampel penelitian yang kurang besar disebabkan kasus HAK di Indonesia masih banyak yang belum terdiagnosis dan belum dilakukan pemeriksaan mutasi gen CYP21. Rasio penelitian kami hampir serupa dengan penelitian di Indonesia. ${ }^{17-22}$ Namun, terdapat perbedaan rasio bila dibandingkan dengan penelitian di luar negeri. ${ }^{11-16}$

Penyakit HAK merupakan kelainan genetik yang bersifat autosomal resesif sehingga diperlukan data mengenai suku/etnis pada subjek dan keluarganya. ${ }^{23}$ Namun, penelitian kami tidak dapat menggambarkan hubungan antara pola mutasi CYP21 berdasarkan suku/etnis yang sesungguhnya terjadi karena perbedaan proporsi suku, dapat disebabkan oleh faktor wilayah geografis, banyaknya perkawinan antar suku, dan diagnosis yang belum merata pada saat penelitian ini dikerjakan. Dengan demikian, diperlukan penelusuran lebih lanjut mengenai data ini.

Konsanguitas adalah hubungan darah, dalam hal ini perkawinan yang memiliki hubungan darah antar kedua orangtua subjek. Konsanguitas merupakan salah satu risiko munculnya kelainan genetik. Hubungan konsanguitas terhadap mutasi CYP21 pada kelainan genetik seperti kasus HAK ini perlu diteliti lebih lanjut untuk melihat adanya suatu kecenderungan pola mutasi tertentu pada kelompok suku/etnis yang cenderung untuk melakukan pernikahan antar anggota keluarganya sendiri. Pada penelitian tidak didapatkan adanya konsanguitas pada seluruh orangtua subjek sehingga hal ini tidak dapat diamati lebih lanjut. Penelitian sebelumnya melaporkan riwayat konsanguitas pada HAK 2,7\%. ${ }^{17}$ Penelitian di luar negeri melaporkan hal yang beragam, bahkan melaporkan konsanguitas terjadi lebih besar pada suku bangsa atau negara tertentu. ${ }^{24} \mathrm{Hal}$ tersebut menjelaskan bahwa perbedaan budaya memiliki pengaruh terhadap konsanguitas yang terjadi pada suatu negara.

Subjek yang terdiagnosis HAK sebelum usia 1 tahun 37 subjek dan yang terdiagnosis di atas usia 1 tahun 8 subjek. Hampir seluruh subjek yang terdiagnosis sebelum usia 1 tahun adalah tipe SW $(96,9 \%)$. Subjek HAK tipe SW terdiagnosis dan mulai terapi lebih dini pada median 1 bulan (rentang 0-3 bulan), tipe SV pada median 3 tahun (rentang 2-6 tahun), dan tipe NC pada usia 5 tahun. Subjek tipe SW dapat terdiagnosis dan mendapatkan terapi lebih dini dibandingkan tipe non-SW. Hal tersebut dapat terjadi karena gejala klinis krisis adrenal pada tipe SW terjadi pada 1 tahun pertama kehidupannya sehingga pasien datang berobat ke dokter lebih dini dibandingkan tipe lainnya.

Keluhan utama pasien, antara lain, genitalia ambigus (60\%), gejala krisis adrenal $(35,6 \%)$, dan memiliki riwayat keluarga HAK (4,4\%). Hal tersebut sesuai dengan penyebab genitalia ambigus tersering 
adalah HAK. ${ }^{3,4}$ Subjek dengan tipe HAK klasik, baik SW maupun SV, dapat didiagnosis lebih dini oleh dokter karena manifestasi genitalia ambigus yang membuat orangtua membawa anaknya ke dokter untuk melakukan evaluasi lebih lanjut terhadap jenis kelamin anak.

Mayoritas tipe HAK adalah tipe SW (73,3\%), tipe SV $(22,2 \%)$, dan tipe NC $(4,4 \%)$. Perbedaan jumlah subjek antara masing-masing tipe HAK, terutama antara HAK klasik dan non klasik, karena di negara berkembang termasuk Indonesia pemeriksaan diagnosis pra-natal dan uji saring neonatus belum secara rutin dilakukan. Hal tersebut menyebabkan jumlah pasien HAK tipe non-klasik di Indonesia jauh lebih sedikit dibandingkan dengan tipe klasik.

Mutasi delesi/LGC adalah mutasi yang paling banyak ditemukan dengan persentasi sekitar 30\%-50\% kemudian diikuti oleh berbagai jenis mutasi yang lain yang berbeda frekuensinya di tiap negara. ${ }^{1,11,16,22-26}$ Individu yang mengalami mutasi delesi/LGC pada gen CYP21 akan kehilangan seluruh kemampuannya untuk mengode pembentukan enzim 21-hidroksilase sehingga akan didapatkan manifestasi klinis yang lebih berat. ${ }^{1,2,5}$ Mutasi I172N menyebabkan aktivitas enzim 21-hidroksilase yang terjadi 1\%-2\%. Berbagai penelitian sebelumnya melaporkan bahwa mutasi ini berhubungan dengan HAK tipe SV dan sebagian kecil tipe SW. ${ }^{1,3}$ Pada penelitian ini, subjek yang mengalami mutasi I172N lebih banyak ditemukan (36/45), dibandingkan dengan subjek yang mengalami mutasi R356W (30/45). Sebagian besar subjek yang mengalami mutasi I172N saja adalah tipe SW (12/33), sedangkan SV lebih sedikit (2/10).

Banyak penelitian yang menyatakan bahwa fenotip yang terjadi dapat bervariasi dan tidak berhubungan dengan genotipnya. ${ }^{8,11,15,27}$ Namun, faktor kemungkinan terbesar pada penelitian ini adalah adanya mutasi tambahan yang belum atau tidak terdeteksi. Batubara mendapatkan 45/50 (90\%) mutasi CYP21 pada subjek penelitiannya, tetapi hanya melakukan pemeriksaan mutasi R356W dan I172N, dan tidak melakukan pemeriksaan mutasi delesi/ LGC maupun mutasi lain. Adanya mutasi lain yang mungkin terjadi, tetapi belum dapat terdeteksi, sangat memengaruhi derajat enzimatik yang sesungguhnya terjadi dan memengaruhi manifestasi klinis subjek pada penelitian ini.

Kemungkinan lainnya adalah akibat kesalahan metode analisis molekular yang dilakukan. ${ }^{27}$ Kesalahan pada saat melakukan DNA sequencing, splicing dan amplifikasi dapat menyebabkan perbedaan hasil yang didapatkan. Perbedaan hasil juga dapat disebabkan oleh kemungkinan kesalahan intrepetasi hasil pada analisis molekular. Gen CYP21 termasuk dalam gen yang sangat polimorfik dalam tubuh manusia dan memiliki pseudogennya yang $98 \%$ nukleotidanya mirip dengan gen aktifnya (CYP21). Dengan demikian, kesalahan juga dapat terjadi akibat duplikasi gen CYP21, kompleks varian gen CYP21 dan pseudogen, serta jumlah pseudogen (CYP21P) dibandingkan gen aktif (CYP21). ${ }^{28-31} \mathrm{Hal}$ tersebut membuat hingga saat ini banyak studi analisis molekular yang paling baik untuk mendeteksi mutasi pada CYP21.

\section{Kesimpulan}

Rasio perempuan hiperplasia adrenal kongenital lebih banyak dibandingkan laki-laki (4,6:1) dengan median usia saat terdiagnosis adalah 1 bulan (rentang 0-3 bulan) pada tipe SW, usia 3 tahun (rentang 2-6 tahun) pada tipe SV, dan usia 5 tahun pada tipe NC. HAK tipe SW lebih banyak ditemukan (73,3\%). Keluhan utama subjek terbanyak saat datang adalah genitalia ambigus (60\%). Subjek yang memiliki riwayat keluarga HAK sebesar 15,6\% dan seluruh orangtua subjek tidak ada yang memiliki konsanguitas. Subjek yang mengalami mutasi I172N lebih banyak ditemukan (36/45) dan memiliki manifestasi klinis yang berbeda-beda. Mutasi R356W ditemukan pada sebagian besar subjek HAK tipe SW (21/33). Perlu dilakukan pemeriksaan mutasi lebih lanjut untuk mengkonfirmasi hubungan antara genotip dan fenotip pada pasien HAK. Pemeriksaan mutasi gen CYP21 bermanfaat untuk konseling genetik, diagnosis prenatal dan tata laksana pada keluarga yang memiliki risiko HAK.

\section{Daftar pustaka}

1. Speiser PW, White PC. Congenital adrenal hyperplasia. N Eng J Med 2003;349:776-88.

2. White PC, Speiser PW. Congenital adrenal hyperplasia due to 21-hydroxylase deficiency. Endocr Rev 2000;21:245-91.

3. Pulungan AB, Siregar CD, Aditiawati, Soenggoro EP, Triningsih E, Suryawan IWB, dkk. Korteks adrenal dan gangguannya. Dalam: Batubara JRL, Tridjaja B, 
Pulungan AB, penyunting. Buku ajar endokrinologi anak. Edisi ke-1. Jakarta: Badan Penerbit Ikatan Dokter Anak Indonesia; 2010.h.251-95.

4. Speiser P, Azziz R, Baskin L, Ghizzoni L, Hensle TW, Merke DP, dkk. Congenital adrenal hyperplasia due to steroid 21-hydroxylase deficiency: an Endocrine Society clinical practice guideline. J Clin Endocrinol Metab 2010;95:4133-60.

5. Marumudi E, Khadgawat R, Surana V, Shabir I, Joseph A, Ammini AC. Diagnosis and management of classical congenital adrenal hyperplasia. Steroids 2013;78:741-6.

6. Tridjaja B. Disorders sex development. Dalam: Batubara JRL, Tridjaja B, Pulungan AB, penyunting. Buku ajar endokrinologi anak. Edisi ke-1. Jakarta: Badan Penerbit Ikatan Dokter Anak Indonesia; 2010.h.62.

7. Ogilvie CM, Crouch NS, Rumsby G, Creighton SM, Liao LM, Conway GS. Congenital adrenal hyperplasia in adults: a review of medical, surgical and psychological issues. Clin Endocrinol 2006;64:2-11.

8. Nordenstrom A, Thilen A, Hagenfeldt L, Larsson A, Wedell A. Genotyping is a valuable diagnostic complement to neonatal screening for congenital adrenal hyperplasia due to steroid 21-hydroxylase deficiency. J Clin Endocrinol Metab 1999;84:1505-9.

9. Krone N, Arlt W. Genetics of congenital adrenal hyperplasia. Best Pract Res Clin Endocrinol Metab. 2009;23:181-92.

10. Forrest MG. Recent advances in the diagnosis and management of congenital adrenal hyperplasia due to 21-hydroxylase deficiency. Hum Reprod Update 2004; 10:469-85.

11. New MI, Abraham M, Gonzalez B, Dumic M, RazzaghyAzar M, Chitayat D, dkk. Genotype-phenotype correlation in 1,507 families with congenital adrenal hyperplasia owing to 21-hydroxylase deficiency. Proc Natl Acad Sci USA 2013;110:2611-6.

12. Stikkelbroeck NM, Hoefsloot LH, de Wijs IJ, Otten BJ, Hermus AR, Sistermans EA. CYP21 gene mutation analysis in 198 patients with 21-hydroxylase deficiency in the Netherlands: six novel mutations and a specific cluster of four mutations. J Clin Endocrinol Metab 2003;88:3852-9.

13. Bas F, Kayserili H, Darendeliler F, Uyguner O, Günöz H, Yüksel Apak M, dkk. CYP21A2 gene mutations in congenital adrenal hyperplasia: genotype-phenotype correlation in Turkish children. J Clin Res Pediatr Endocrinol 2009;1:116-28.

14. Dung VC, Khanh TV, Fukami M, Phuong LT, Ha NT,
Liem NT, dkk. Mutation spectrum of CYP21A2 and correlation between genotype-phenotype in 81 Vietnamese patients with congenital adrenal hyperplasia due to 21-hydroxylase deficiency. Int J Pediatr Endocrinol 2013;2013:128.

15. Krone N, Rose IT, Willis DS, Hodson J, Wild SH, Doherty EJ, dkk. Genotype-phenotype correlation in 153 adult patients with congenital adrenal hyperplasia due to 21-hydroxylase deficiency: analysis of the United Kingdom congenital adrenal hyperplasia adult study executive (CaHASE) cohort. J Clin Endocrinol Metab 2013;98:346-54.

16. Balraj P, Lim PG, Sidek H, Wu LL, Khoo AS. Mutational characterization of congenital adrenal hyperplasia due to 21-hydroxylase deficiency in Malaysia. J Endocrinol Invest. 2013;36:366-74.

17. Oswari AW. Deteksi delesi/large gene conversion dan mutasi titik kodom 172 gen CYP21 pada hiperplasia adrenal kongenital, tesis. Jakarta: FKUI, 2007.

18. Batubara JRL, Tridjaja B, Prayitno L. Polimorfisme gen CYP21 pada anak dengan defisiensi steroid 21-hidroksilase di Indonesia: pengembangan diagnosis molekuler hiperplasia adrenal kongenital, riset. Jakarta: FKUI, 2011.

19. Widodo AD. Karakteristik densitas tulang anak dengan hiperplasia adrenal kongenital yang mendapat terapi glukokortikoid, tesis. Jakarta: FKUI, 2010.

20. Susanti I. Karakteristik anak hiperplasia adrenal kongenital terkait obesitas sebagai akibat dari penyakit dan terapi, tesis. Jakarta: FKUI,2013.

21. Sari NIN. Manifestasi pubertas dan pertumbuhan linear pada penderita hyperplasia adrenal kongenital dalam terapi, tesis. Jakarta: FKUI, 2013.

22. Goossens K, Juniarto AZ, Timmerman MA, Faradz SM, Wolffenbuttel KP, Drop SL, dkk. Lack of correlation between phenotype and genotype in untreated 21-hydroxylase-deficient Indonesian patients. Clin Endocrinol 2009;71:628-35.

23. Wilson RC, Nimkarn S, Dumic M, Obeid J, Azar M, Najmabadi H, dkk. Ethnic-specific distribution of mutations in 716 patients with congenital adrenal hyperplasia owing to 21-hydroxylase deficiency. Mol Genet Metabol 2007;90:414-21.

24. Kharrat M, Tardy V, M'Rad R, Maazoul F, Jemaa LB, Refaï M, dkk. Molecular genetic analysis of Tunisian patients with a classic form of 21-hydroxylase deficiency: identification of four novel mutations and high prevalence of Q318X mutation. J Clin Endocrinol Metab 2004;89:368-74. 
25. Marumudi E, Sharma A, Kulshreshtha B, Khadgawat R, Khurana ML, Ammini AC. Molecular genetic analysis of CYP21A2 gene in patients with congenital adrenal hyperplasia. Indian J Endocrinol Metab 2012;16:384-8.

26. Marino R, Ramirez P, Galeano J, Perez Garrido N, Rocco C, Ciaccio M, dkk. Steroid 21-hydroxylase gene mutational spectrum in 454 Argentinean patients: genotype-phenotype correlation in a large cohort of patients with congenital adrenal hyperplasia. Clin Endocrinol 2011;75:427-35.

27. Wilson RC, Mercado AB, Cheng KC, New MI. Steroid 21-hydroxlase deficiency: genotype may not predict phenotype. J Clin Endocrinol Metab 1995;80:2322-9.
28. Lee H. Variants of the CYP21A2 and CYP21A1P genes in congenital adrenal hyperplasia. Clin Chim Acta 2013;418:37-44.

29. Tsai LP, Cheng CF, Chuang SH, Lee HH. Analysis of the CYP21A1P pseudogene: indication of mutational diversity and CYP21A2-like and duplicated CYP21A2 genes. Anal Biochem 2011;413:133-41.

30. Tsai LP, Lee HH. Analysis of CYP21A1P and the duplicate CYP21A2 genes. Gene 2012:506:261-2.

31. Leccese A, Longo V, Dimatteo C, De Girolamo G, Trunzo R, D’Andrea G, dkk. Lack of genotypephenotype correlation in congenital adrenal hyperplasia due to a CYP21A2-like gene. Clin Chim Acta 2014;437:48-51. 